\title{
Evaluation of diagnostic examinations of lactose intolerance in children
}

\author{
Ocena badań diagnostycznych w nietolerancji laktozy u dzieci
}

\author{
Sabina Więcek, Halina Woś, Urszula Grzybowska-Chlebowczyk \\ Department of Paediatrics at Silesian Medical University, Silesian Centre of Child's and Mother's Health, Katowice, Poland
}

Przegląd Gastroenterologiczny 2010; 5 (2): 94-98

DOI: $10.5114 /$ pg.2010.14037

Key words: lactase activity, hydrogen breath test, oral lactose load test with determination of glucose concentration in capillary blood.

Słowa kluczowe: aktywność laktazy, wodorowy test oddechowy, doustny test obciążenia laktozą z oceną stężenia glukozy we krwi włośniczkowej.

Address for correspondence: Sabina Więcek, Department of Paediatrics, Silesian Medical University, ul. Medykow 16, 40-752 Katowice, Poland, phone +48 3220717 00, fax +48 3220717 21, e-mail: sabinawk@wp.pl

\begin{abstract}
Introduction: The diagnosis of lactose intolerance is established on the basis of the clinical picture, the hydrogen breath test and/or determined concentration of glucose in the blood after the oral lactose load. The most valuable examination seems to be the determination of lactase activity in the intestinal biopsy. However, in the literature there are only a few studies comparing these diagnostic methods.

Aim: To evaluate the sensitivity and specificity of the hydrogen breath test and the evaluation of glucose concentration in the blood after lactose load in comparison with lactase activity in the intestinal biopsy.

Material and methods: In 61 children we performed the hydrogen breath test and the oral lactose load test with determination of glucose concentration in the blood, and we determined lactase activity in the intestinal biopsy.

Results: In $79 \%$ of the patients we observed compatibility between the hydrogen breath test and lactase activity, in $16.6 \%$ the hydrogen breath test gave false positive results, and in $4.4 \%$ the results were false negative. In a majority of the patients with false positive results of the hydrogen breath test, lactase levels were in the low normal range. The oral lactose load test with the determination of glucose concentration in the blood was characterized by lower sensitivity and specificity. In over $20 \%$ it showed false positive results and in $10 \%$ false negative results.

Conclusions: With regard to the large number of false positive and negative results in the hydrogen breath test and the oral lactose load test with the determination of glucose concentration in the blood, in the case of diagnostic difficulties it seems reasonable to determine lactase activity in the intestinal biopsy.
\end{abstract}

\section{Streszczenie}

Wstęp: Rozpoznanie nietolerancji laktozy ustala się na podstawie obrazu klinicznego, wyniku wodorowego testu oddechowego i/lub oznaczanego stężenia glukozy we krwi włośniczkowej po doustnym obciążeniu laktozą. Najbardziej miarodajnym badaniem wydaje się oznaczanie aktywności laktazy w bioptatach błony śluzowej jelita cienkiego. W piśmiennictwie jest jednak bardzo mało prac porównujących te metody diagnostyczne.

Cel: Ocena czułości i swoistości wodorowego testu oddechowego i oznaczenia stężenia glukozy we krwi włośniczkowej po obciążeniu laktozą w porównaniu z aktywnością laktazy w bioptacie błony śluzowej jelita cienkiego.

Materiał i metody: $\cup 61$ dzieci wykonano wodorowy test oddechowy, doustny test obciążenia laktozą z oznaczeniem stężenia glukozy we krwi włośniczkowej oraz oznaczenie aktywności laktazy w bioptatach błony śluzowej jelita cienkiego. Wyniki: U 79\% chorych stwierdzono zgodność między wynikiem wodorowego testu oddechowego i aktywnością laktazy. U 16,6\% osób wodorowy test oddechowy dał wynik fałszywie dodatni, natomiast u 4,4\% fałszywie ujemny. U większości pacjentów z fałszywie dodatnim wynikiem wodorowego testu oddechowego wartości laktazy były zawarte w pobliżu dolnej granicy normy. Mniejszą czułością i swoistością charakteryzował się doustny test obciążenia laktozą z oznaczeniem stężenia glukozy we krwi włośniczkowej. W ponad $20 \%$ dat on wynik fałszywie dodatni i w 10\% wynik fałszywie ujemny. Wnioski: Ze względu na dużą liczbę wyników fałszywie dodatnich i ujemnych testów nieinwazyjnych - wodorowego testu oddechowego i testu doustnego obciążenia laktozą z oznaczeniem stężenia glukozy we krwi włośniczkowej - w przypadku trudności diagnostycznych celowe wydaje się oznaczanie stężenia aktywności laktazy w bioptatach błony śluzowej jelita cienkiego. 


\section{Introduction}

Lactose intolerance includes a group of clinical symptoms such as: nausea, vomiting, abdominal pain, fullness and diarrhoea, which appear after lactose intake or after a load of this disaccharide. Lactose intolerance is connected with the presence of lactose in the lumen of the large intestine and intensification of the process of fermentation caused by intestinal flora. As a result of these processes short-chained fatty acids appear and cause a change of the $\mathrm{pH}$ of intestinal contents, the acceleration of peristaltic movement and secondarily, diarrhoea, pain and abdominal flatulence.

The prevalence of lactose intolerance varies greatly between countries. Lactose intolerance is diagnosed in over $50 \%$ of adult people of South America and Africa, but is diagnosed in $15 \%$ of white people in the United States, $53 \%$ of Mexicans and $80 \%$ of black people.

Adult-type hypolactasia in Europe occurs with different rates (the least frequent in Scandinavia, 2\%, the most frequent in Sicily, 70\%). The incidence of lactose intolerance in adult people in Poland is about $35 \%$, although in children aged between 7 and 15 years it is lower, about 20\% [1-3].

Lactose transformation in the intestine depends not only on lactase activity but also on the frequency and amplitude of stomach emptying, intestinal passage, intestinal microflora and the response of the large intestine to the osmotic load. Several authors are of the opinion that only half of patients with lactose intolerance have clinical symptoms. There is not a uniform minimal dose of lactose which causes clinical symptoms in patients with diagnosed intolerance of this disaccharide. A majority of patients do not have clinical symptoms even after drinking two glasses of milk [1]. The symptoms of lactose intolerance may be similar to the symptoms observed in organic or functional diseases of the alimentary tract.

The diagnosis of lactose intolerance is established on the basis of the clinical picture, evaluation of $\mathrm{pH}$ of stool and the presence of reducing substances in it, determination of glucose concentration in the capillary blood and/or results of the hydrogen breath test after oral lactose load. However, each of these examinations may give a high percentage of both false positive and false negative results. The diagnosis of lactose intolerance may be established on the basis of elimination of milk from the diet for two weeks and remission of ailments can suggest a suspicion of lactose intolerance. According to literature, the most valuable examination seems to be evaluation of lactase activity in biopsy specimens from the small intestine mucosa; however, it is an invasive examination [4-6].

\section{Aim}

The aim of the study was to evaluate selected tests used in the diagnosis of lactose intolerance (the hydrogen breath test and oral lactose load test with determination of glucose concentration in the capillary blood) in comparison with lactase activity in the small intestine mucosa.

\section{Material and methods}

The examined group included 61 children (31 girls $50.8 \%$, 30 boys $-49.2 \%$ ), aged from 3 to 18 years (mean age 11 years), who were patients of the Department of Gastroenterology at the Silesian Medical University in Katowice due to abdominal pain and/or body mass deficiency. The diagnostics of lactose intolerance included the clinical picture, lactase activity in the biopsy specimens from the small intestine mucosa and results of the hydrogen breath test and the oral lactose load test with evaluation of glucose concentration in the capillary blood.

We compared lactase activity in the biopsy specimens from the small intestine with the results of the hydrogen breath test and the oral lactose load test with determination of glucose concentration in the capillary blood.

Lactase activity in the biopsy specimens of the small intestine mucosa was determined using Dahlquist's method in Dyduch's modification. This method is based on the enzymatic evaluation of disaccharidase activity in a homogenised small intestine tissue sample (disaccharidase activity is expressed in umol of decomposed disaccharide in $1 \mathrm{~min}$ of incubation per gram of mucous membrane homogenate) $[7,8]$.

As a norm we accepted the range of lactase from 1.0 to $19.0 \mathrm{U} / 1 \mathrm{~g}$ of tissue. During the endoscopic examination we took biopsy specimens from the descending part of the duodenum in order to determine lactase activity. The biopsy specimens were frozen at a temperature of minus $20^{\circ} \mathrm{C}$ in isotonic salt solution and stored until the evaluation of lactase activity, no longer than four weeks.

The endoscopic examination of the upper part of the alimentary tract, including taking biopsy specimens from the descending part of the duodenum, was performed using the Olympus endoscope (in younger children - GIV N30, GIV P140; in older children - GIV V2). An indication for the endoscopic examination was a suspicion of malabsorption syndrome and an investigation of the causes of abdominal pain.

The hydrogen breath test was performed by measuring the amount of exhaled hydrogen before and after 30,60, 90 and 120 min of the oral lactose load in 
the amount of $1.75 \mathrm{~g} / \mathrm{kg}$ of body mass (max. $50 \mathrm{~g}$ ). As a positive result indicating lactose intolerance we accepted an increase of hydrogen in exhaled air over 20 ppm after lactose load.

In all the children we evaluated glucose concentration in the capillary blood while fasting and after 30, 60 and $90 \mathrm{~min}$ of the oral lactose load in the amount of $1.75 \mathrm{~g} / \mathrm{kg}$ (max. $50 \mathrm{~g}$ ). As a result indicating lactose intolerance we accepted an increase of glucose concentration in blood of less than $20 \mathrm{mg} \%$.

All those examined were informed about the method and the aim of the examination. We obtained the written consent of parents, and the consent of children if they were over 16 years old, to take additional biopsy specimens of the mucosa of the duodenum.

We obtained the consent of the Committee of Bioethics of the Silesian Medical University (NN-013220/00)

For the evaluation of sensitivity and specificity of the tests used in lactose intolerance the Youden index (J) was used.

\section{Results}

In the clinical picture of examined children abdominal pain and body mass deficiency dominated. Clinical symptoms observed in examined children are presented in Table I.

In 10 patients decreased lactase concentration in biopsy specimens from the small intestine mucosa was detected. In anamnesis these patients reported chronic diarrhoea, abdominal pain, flatulence and vomiting.

In all patients with decreased lactase activity in small intestine mucosa specimens and positive results of the hydrogen breath test, lactose administration was followed by positive results of the clinical test: abdominal pain, flatulence, diarrhoea and/or vomiting.

Among patients with positive results of the hydrogen breath test and values of lactase in small intestine mucosa specimens at the lower limit of normal, in $70 \%$ clinical symptoms appeared after lactose administration in the provocation test.

In the diagnosis of lactose intolerance we performed the evaluation of lactase activity in biopsy specimens from the small intestine mucosa, the hydrogen breath test and the oral lactose load test with determination of glucose concentration in the capillary blood. We compared the compatibility of the results obtained in the hydrogen breath test and the oral lactose load test with determination of glucose concentration in the capillary blood in relation to the results of lactase activity in the biopsy specimens of the small intestine mucosa. Decreased lactase activity was found in 10 children (16.4\%) (Table II).

In 36 patients (59\%) we observed normal results of the hydrogen breath test and the oral lactose load with determination of glucose concentration in the capillary blood and normal lactase activity in the biopsy specimens from the small intestine mucosa. In 48 patients (79\%) we observed compatibility between the hydrogen breath test and lactase activity. In 10 patients (16.6\%) the hydrogen breath test gave false positive results and in 3 children (4.4\%) false negative results.

In a majority of patients with false positive results of the hydrogen breath test the levels of lactase were in the low normal range; these patients may develop full symptomatic lactose intolerance in the future.

Table I. Clinical symptoms in examined patients

Tabela I. Objawy kliniczne u badanych pacjentów

\begin{tabular}{lccccc} 
& $\begin{array}{c}\text { Abdominal } \\
\text { pain }\end{array}$ & $\begin{array}{c}\text { Body mass } \\
\text { deficiency }\end{array}$ & $\begin{array}{c}\text { Recurrent } \\
\text { vomiting }\end{array}$ & $\begin{array}{c}\text { Chronic } \\
\text { diarrhoea }\end{array}$ & Constipation \\
\hline $\begin{array}{l}\text { Examined group } \\
(n=61)\end{array}$ & $62.5 \%$ & $52.5 \%$ & $35 \%$ & $17.5 \%$ & $5 \%$ \\
& $n=38$ & $n=32$ & $n=21$ & $n=11$ & $n=3$
\end{tabular}

Table II. Lactase activity in examined children

Tabela II. Aktywność laktazy u badanych dzieci

\begin{tabular}{|c|c|c|c|c|}
\hline & \multicolumn{3}{|c|}{ Lactase activity } & \multirow[t]{2}{*}{ Total } \\
\hline & Decreased & Normal & Increased & \\
\hline Examined group & $16.4 \%$ & $75.5 \%$ & $8.1 \%$ & $100 \%$ \\
\hline$N=61$ & $N=10$ & $N=46$ & $N=5$ & $N=61$ \\
\hline Min. activity & 0.0 & 1.3 & 21.6 & 0.0 \\
\hline Max. activity & 0.98 & 17.56 & 76.85 & 76.85 \\
\hline Mean activity & 0.56 & 4.5 & 46.8 & 7.32 \\
\hline
\end{tabular}


The oral lactose load test with determination of glucose concentration in the capillary blood was characterized by lower sensitivity and specificity. In 13 children (23\%) this test gave false positive results and in 6 children (10\%) false negative results (Table III).

On the basis of the Youden index we evaluated sensitivity, specificity and reliability of positive and negative results of the hydrogen breath test and the oral lactose load test with determination of glucose concentration in the capillary blood.

\author{
Hydrogen breath test \\ - sensitivity - 94\% \\ - specificity $-45 \%$ \\ - reliability of positive results $-78 \%$ \\ - reliability of negative results $-71 \%$
}

\author{
Oral lactose test with determination of glucose \\ concentration \\ - sensitivity $-85 \%$ \\ - specificity - 30\% \\ - reliability of positive results $-74 \%$ \\ - reliability of negative results $-47 \%$
}

\section{Discussion}

The evaluation of lactase activity in biopsy specimens from the small intestine mucosa is considered to be one of the most authoritative examinations used in the diagnosis of lactose intolerance. However, it is an invasive examination which requires taking a biopsy specimen from the small intestine during the endoscopy or using a Crosby capsule, most frequently in the state of general anaesthesia.

In several studies the authors attempted to compare sensitivity and specificity of non-invasive tests used in diagnosing hypolactasia with an invasive test such as evaluation of lactase activity in biopsy specimens from the mucosa of the alimentary tract [9-11]. The oral lactose load tests are useful because of the simplicity of performance and small invasiveness. However, these tests may give both false positive and false negative results.

In our study the oral lactose load test with determination of glucose concentration in the capillary blood was characterized by quite high sensitivity, about $85 \%$, but low specificity. We found that the reliability of positive results was $74 \%$, but the reliability of negative results was only $47 \%$.

Harrison criticized the importance of the oral lactose load test with determination of glucose concentration in the capillary blood in diagnosis of hypolactasia; he did not find a correlation between a flat curve of lactose load, clinical symptoms and lactase activity. The oral lactose
Table III. Evaluation of the hydrogen breath test and the oral lactose load test with determination of glucose concentration in the capillary blood in comparison with lactase activity in the biopsy specimens from the small intestine mucosa

Tabela III. Ocena wyników wodorowego testu oddechowego i doustnego testu obciążenia laktoza z ocena stężenia glukozy we krwi włośniczkowej w porównaniu z aktywnościa laktazy $w$ bioptatach błony śluzowej jelita cienkiego

\begin{tabular}{lcc} 
& $\begin{array}{c}\text { Hydrogen } \\
\text { breath } \\
\text { test }\end{array}$ & $\begin{array}{c}\text { Oral lactose load } \\
\text { test with } \\
\text { determination } \\
\text { of glucose } \\
\text { concentration } \\
\text { in the capillary blood }\end{array}$ \\
\hline Compatible results [\%] & 79 & 67 \\
\hline False positive results [\%] & 16.6 & 23 \\
\hline False negative results [\%] & 4.4 & 10
\end{tabular}

load test gave both false positive and false negative results in a large percentage. Moreover, he claims that a physiological flat sugar curve occurs in $30 \%$ of people [12].

Bode discovered compatibility between lactase activity and the results of the oral lactose load test with determination of glucose concentration in the capillary blood only in $76 \%$ of patients [13].

In our study the hydrogen breath test proved to be a much better examination; its sensitivity was $94 \%$, the reliability of positive results was $78 \%$, and the reliability of negative results was $71 \%$. We found a strict correlation between the intensification of ailments and the maximum increase of hydrogen in the exhaled air.

Lember also emphasizes better sensitivity and specificity of the hydrogen breath test in comparison with the determination of glucose concentration in the capillary blood after lactose load [14].

Socha claims that the sensitivity of the hydrogen breath test reaches $79-100 \%$ and its specificity $92-100 \%$ [15]. Our results were slightly worse. The hydrogen breath test may give false negative results in patients after taking antibiotics and long-term treatment with salicylates, after resection of the large intestine and in patients with disorders of stomach emptying. On the other hand, false positive results may be observed in patients with bacterial hypertrophy of the small intestine, in active smokers, in patients receiving bicarbonates and in people with dental caries [6].

Di Stefano is of the opinion that a prolongation of the time of examination until $3 \mathrm{~h}$ and decreased diagnostic criteria (hydrogen concentration in exhaled air > 6 ppm) can increase the sensitivity of the hydrogen breath test 
[16]. Arola evaluates specificity of the hydrogen breath test as $89-100 \%$ and its sensitivity as $69-100 \%$ [17].

Pfefferkorn evaluates sensitivity and specificity of the hydrogen breath test as nearly $100 \%$ in adults, and in children as only $75-77 \%$ [18]. The excretion of hydrogen during the oral lactose load test is much lower than in patients over 70 years old. Therefore, it is suggested that this test may have limited use in elderly people $[1,6]$.

It is also possible that the evaluation of lactase activity in biopsy specimens from the small intestine mucosa is not a very reliable method, because it only shows the activity in the place of the biopsy. It is reliable in the case of extensive changes, but in the case of focal changes it can lead to false conclusions.

Lower values of disaccharidase activity taken by endoscopic method than by Crosby's capsule were also found by Kappler. It can be explained by higher localization of taken bioptates or different proportion of villi to interstitial [19].

Perhaps in the future genetic examinations will play a crucial role in diagnostics of lactose intolerance. At present the molecular studies aimed at this problem (detection of mutation C/T-13910) evaluate the sensitivity of this examination as $93 \%$ and its specificity as $100 \%$ [20, 21].

Lopes compared molecular studies with the hydrogen breath test. All patients with positive results of the hydrogen breath test had the positive genotype C/T 13910 . There was no patient who had a positive result of the hydrogen breath test with an accompanying negative result of the molecular examination. However, in 3 patients with a positive molecular examination there were negative results of the hydrogen breath test. It is possible that the symptoms of lactose intolerance will appear in these patients later on or these patients belong to socalled "non-excreters" [22].

With regard to the large number of false positive and false negative results of the hydrogen breath test and the evaluation of glucose concentration in the capillary blood after lactose load (in the case of diagnostic difficulties), it seems reasonable to determine lactase activity in biopsy specimens from the small intestine, and in the future to perform genetic examinations.

\section{References}

1. Montalto M, Curigliano V, Santoro L, et al. Management and treatment of lactose malabsorption. World J Gastroenterol 2006; 12: 187-91.

2. Hutyra T, Iwańczak B. Lactose intolerance: pathophysiology, clinical symptoms, diagnosis and treatment. Pol Merkur Lekarski 2009; 26: 148-52.

3. Escoboza PM, Fernandes MI, Peres LC, et al. Adult - type hypolactasia: clinical, morphologic and functional charac teristics in brazilian patients at a university hospital. J Pediatr Gastroenterol Nutr 2004; 4: 361-5.
4. Dahlquist A. Assay of intestinal disaccharidases. Scand J Clin Lab Invest 1984; 44: 169-72.

5. Malagelada J. Lactose intolerance. N Engl J Med 1995; 333: 53-5.

6. Hovde Q, Farup P. A comparison of diagnostics tests for lactose malabsorption - which one is the best? BMC Gastroenterol 2009; 31: 82-5.

7. Dyduch A, Karczewska K. Prosta, ilościowa metoda oznaczania dwusacharydaz w błonie śluzowej jelita. Diagn Lab 1978; 6: 333-5.

8. Dahlqvist A. Assay of intestinal disaccharidases. Anal Biochem 1968; 22: 99-107.

9. Argnani F, Di Camillo M, Marinaro V, et al. Hydrogen breath test for the diagnosis of lactose intolerance, is the routine sugar load the best one? World J Gastroenterol 2008; 28: 6204-7.

10. Shaw AD, Davies GJ. Lactose intolerance problems in diagnosis and treatment. J Clin Gastroenterol 1999; 28: 208-16.

11. Gupta SK, Chong SK, Fitzgerald JF. Disaccharidase activities in children: normal values and comparison based on symptoms and histologic changes. J Pediatr Gastroenterol Nutr 1999; 28 : 246-51.

12. Harrison M, Walker-Smith JA. Reinvestigation of lactose intolerant children: lack of correlation between continuing lactose intolerance and small intestinal morphology, disaccharidase activity and lactose tolerance tests. Gut 1977; 18: 48-52.

13. Bode S, Gudmand-Hoyer E. Incidence and clinical significance of lactose malabsorption in adult coeliac disease. Scand J Gastroenterol 1988; 23: 484-8.

14. Lember M. Assesment of lactose tests. Am Fam Physician 2002; 66: 2206-8.

15. Socha J, Stolarczyk A. The fermented milk and lactose intolerance in children. Żyw Człow Metab 1999; 26 supl.: 23-9.

16. Di Stefano M, Missanelli A, Miceli E, et al. Hydrogen breath test in the diagnosis of lactose malabsorption: accuracy of new versus conventional criteria. J Lab Clin Med 2004; 144: 313-8.

17. Arola H. Diagnosis of hypolactasia and lactose malabsorption. Scand J Gastroenterol 1994; 29 (Suppl 202): 26-35.

18. Pfefferkorn MD, Fitzgerald JF, Croffie JM, et al. Lactase deficiency: not more common in paediatric patients with inflammatory bowel disease than in patients with chronic abdominal pain. J Pediatr Gastroenterol Nutr 2002; 35: 339-43.

19. Kappler M, Lang T, Heilig G, et al. Disaccharidase activities in small bowel biopsies : comparison of suction capsule versus endoscopic biopsy. J Pediatr Gastroenterol Nutr 2003; 36: 580-3.

20. El-Baba M, Tolia V. A prospective study to diagnose adult type hypolactasia by correlating results of hydrogen breath testing and determination of lactasa - none persistence gene. J Pediatr Gastroenterol Nutr 2004; 39 suppl. 1: 87-92.

21. Schirru E, Usai-Satta P, Jores R, Congia M. Lactose malabsorption: genetic testing versus lactose hydrogen breath test. Dig Liver Dis 2009; 41: 474-79.

22. Lopes A, Coelho M, Figueiredo I, et al. Lactose intolerance in Portugal and Sao Tome (West Africa): prevalence and concordance between molecular diagnosis and breathhydrogen test. O0090 ESPGHAN 2004. J Pediatr Gastroenterol Nutr 2004; 39 suppl. 1: 42. 